\title{
High prevalence of late diagnosis of HIV in Mexico during the HAART era
}

\author{
Brenda Crabtree-Ramírez, MD, (I) Yanink Caro-Vega, MSc,(I) \\ Francisco Belaunzarán-Zamudio, MD, (2) Juan Sierra-Madero, MD.(I)
}

\section{Crabtree-Ramírez B, Caro-Vega Y, Belaunzarán-Zamudio F, Sierra-Madero J. High prevalence of late diagnosis of HIV in Mexico during the HAART era. Salud Publica Mex 20 I2;54:506-5 I4.}

\begin{abstract}
Objective. To evaluate the prevalence of late HIV diagnosis $\left(C D 4<200\right.$ cell $/ \mathrm{mm}^{3}$ ) in an HIV clinic in Mexico City between 200I-2008, to assess changes in this prevalence across the study period, and to determine the risk factors associated to late testing (LT). Materials and methods. Cross-sectional analysis including all patients recently diagnosed as HIV. We estimated the proportion of LT patients and compared demographic characteristics between those and all other. We determine the risk factors associated to LT using logistic regression methods. Results. Sixty one percent of LT patients present when are diagnosed for the first time. The prevalence did not decrease between $200 \mathrm{I}$ and $2008(p=0.37)$. Older age (OR: $2.4 ; 95 \% \mathrm{Cl}$ I.2-4.7), unemployment (OR: I.75; $95 \% \mathrm{Cl}$ I.12-2.75) and less than nine years of education (OR: 2.44; $95 \% \mathrm{Cl}$ I.37-4.33) were independently associated to LT, in a multivariate analysis. Conclusions. LT has high prevalence in Mexico, this impact on antiretroviral effectiveness and perhaps on HIV transmission. Policies for HIV-prevention in Mexico need to be modified to reduce LT prevalence including more aggressive strategies of testing.
\end{abstract}

Key words: Delayed diagnosis; HIV; risk factors; Mexico
Crabtree-Ramírez B, Caro-Vega Y, Belaunzarán-Zamudio F, Sierra-Madero J. Alta prevalencia de diagnóstico tardío de VIH durante la era TARAA en México. Salud Publica Mex 20I2;54:506-5 I4.

\section{Resumen}

Objetivo. Estimar la prevalencia de diagnóstico tardío (DT) (CD4<200 cel/ $/ \mathrm{mm}^{3}$ ) de VIH en una clínica en la Ciudad de México entre 200 l y 2008 , evaluar cambios en la prevalencia en este periodo y determinar factores de riesgo asociados con el DT. Material y métodos. Mediante un estudio de cohorte transversal de pacientes de $\mathrm{VIH}$ se estimó la proporción de pacientes con DT y se compararon sus características demográficas con pacientes sin DT. Se evaluaron los factores de riesgo asociados a DT usando regresión logística. Resultados. Se encontró una prevalencia de DT de $61 \%$, sin cambios entre 200I-2008 ( $p=0.37)$. Mayor edad (RM: 2.4; 95\%IC I.2-4.7), desempleo (RM: I.75; 95\%IC I.12-2.75) y menos de nueve años de educación (RM: 2.44 ; 95\%IC I.37-4.33) fueron independientemente asociados a DT. Conclusiones. El DT tiene alta prevalencia en México. Esto impacta en la efectividad de tratamiento antirretroviral y posiblemente en la transmisión del VIH. Deben dirigirse políticas de prevención a reducir el DT mediante estrategias agresivas de diagnóstico.

Palabras clave: diagnóstico tardío; $\mathrm{VIH}$; factores de riesgo; México

(I) Instituto Nacional de Ciencias Médicas y Nutrición, Salvador Zubirán. Mexico.

(2) Department of International Health, Johns Hopkins Bloomberg School of Public Health. USA.

Received on: September 5, 20II - Accepted on: June 4, 2012

Corresponding author: Mtro. Juan Sierra-Madero. Clínica de VIH/SIDA, Departamento de Infectología,

Instituto Nacional de Ciencias Médicas y Nutrición Salvador Zubirán. Vasco de Quiroga I5, col. Sección XVI. I4000, México DF, México.

E-mail: jsmadero@yahoo.com 
$\mathrm{I}^{\mathrm{n}}$ recent years a strong tendency towards earlier initiation of highly active antiretroviral therapy (HAART) for the treatment of HIV infection has been established because of a better outcome in terms of survival and AIDS complications. ${ }^{1-5}$ HAART initiation in advanced stages has been associated with increased early mortality, costs of care and lower virologic and immunologic efficacy of therapy. ${ }^{2-3,6}$ In addition, ARV treatment has now been proved a powerful effective tool for prevention of transmission. 7,8 Therefore, early access to HIV diagnosis constitutes a major public health issue. Despite efforts to improve the care of people living with HIV, there is still a considerably proportion of subjects who seek medical attention in a very advanced stage of the disease. ${ }^{9-13}$

In Mexico, free universal access to antiretroviral therapy started in 2000. ${ }^{14}$ However, mortality attributed to AIDS related events, has not changed in the last decade $\mathrm{e}^{15}$ and late testing could play an important role in the lack of decrease in mortality related to HIV infection. ${ }^{16}$ Several recent studies in developing countries have shown a prevalence of 20 to $40 \%$ of late diagnosis (most of the studies defined "late testers" as those who present with less than 200 CD4 cell counts and/or a history of AIDS defining illness). ${ }^{12}$ There are several reports in Latin America regarding the high frequency of late stage of disease at diagnosis and initiation of clinical care; ${ }^{16-18}$ however, there is a lack of studies identifying the risk factors associated with this phenomenon. Therefore, the aims of this study were to evaluate the prevalence of late HIV diagnosis in our site, to assess changes in this prevalence across the study period, and to determine the risk factors associated to late diagnosis.

\section{Materials and methods}

\section{Study design and population}

The source population for this cross-sectional analysis was all HIV-infected adults receiving medical care at the HIV / AIDS Clinic at the Instituto Nacional de Ciencias Médicas y Nutrición Salvador Zubirán (INCMNSZ). The INCMNSZ is a tertiary care referral center located in Mexico City that provides medical attention to people from this urban region and also, different regions of the country. Patients included in this analysis were those who attended the clinic for the first time between January 2001 and December 2008, that have been recently diagnosed with HIV-infection (defined as those diagnosed in the previous 6 months), had a CD4+ T cells measurement at or within the previous six months to their admission or have had an AIDS defining illness. We used the 6 month period inclusion criteria to include only those patients considered as true "late-testers" and exclude patients that may have had access to HIV testing earlier, but had barriers for access to health care. Patients for whom the date of diagnosis of HIV infection was missing and those who had more than three months of HAART initiation prior their entrance to our Clinic, were excluded from the analysis.

\section{Data collection}

Patients were identified and information for this analysis was collected using the database of the HIV/AIDS Clinic from the INCMNSZ. The HIV/AIDS Clinic has been prospectively recording demographic, clinical and laboratory information with appropriate dates for all patients since 2000, in every medical visit. The database is updated routinely.

\section{Definitions and measurements}

\section{Outcome}

Patients recently diagnosed with HIV-infection were defined as "late testers" (LT) if they presented with an AIDS defining event (ADE) according to the CDC staging criteria ${ }^{19}$ or developed it in the following six months, had an initial CD4 ${ }^{+}$cell count lower than $200 / \mathrm{mm},{ }^{3}$ or both. Patients considered to be "non-late testers" (NLT) were those who were also recently diagnosed as being HIV-positive, but did not have an AIDS defining condition at diagnosis and for the following six months and had a CD4 ${ }^{+}$count $\geq 200 \mathrm{cell} / \mathrm{mm}^{3}$ at diagnosis.

\section{Explanatory variables}

We collected data on sex, age (categorized in three groups: less than 34,34 to 45 , and above 45 ), risk factor for transmission (men who have sex with men and other), marital status, educational status (categorized in two groups: nine years of education or lower or more than nine years according to the median years of education of the Mexican population), employment status at entrance (employed / unemployed), and socioeconomic status. The socioeconomic status classification was based on an ad hoc institutional system, which ranks patients on a scale from 1 (lowest) through 7 (highest) based on their ability to pay the hospital fees. This classification was further categorized in three groups to simplify the analysis [low SES (scale 1 and 2), middle SES (scale 3) and high SES (higher than 3) socioeconomic status].

\section{Statistical analysis}

We used simple proportions to estimate the proportion of patients that were diagnosed as being HIV-infected 
in advanced stages of the disease (late diagnosis) and to describe the distribution of the associated risk factors with late testing in the total of patients. To assess whether there was any change in the trend of late presentation across the study period, we used an univariated logistic regression model to test the effect of every calendar year on the proportion of LT, between 2001 and 2008. To determine the risk factors associated with late presentation we used a multivariable logistic regression model including all variables (sex, age, route of transmission, marital and employment status, years of education and year of the HIV diagnosis) to estimate the odds ratios (OR) with 95\% confidence intervals and associated $p$-values for the association between being "late-tester" and the explanatory variables, and control for the possible confounding effects of these variables. A Type I error probability of 0.05 was used as threshold for statistical significance. Statistical analyses were performed using STATA version 9.

\section{Results}

A total of 1095 subjects were admitted to the HIV Clinic between January 2001 and December 2008. Four hundred and twenty-nine had a diagnosis of HIV infection within the last 6 months, and a CD4+ cell determination, thus were eligible for the analysis (figure 1). The median $\mathrm{CD}^{+}$count at entrance was $149 \mathrm{cell} / \mathrm{mm}^{3}$ (IQR: 50-287). Most patients were male [ $\mathrm{n}=382(89 \%)]$, their mean age was 35 years (range 28-74 years), and had in average 11.75 years of education $(\mathrm{SD} \pm 4.06)$. Sixty-three $(15 \%)$ were married at entrance and $168(41 \%)$ unemployed. According to their transmission groups, $278(65 \%)$ were classified as Men who have sex with men (MSM).

\section{Prevalence of late testers}

In total $264(61 \%)$ were considered as LT (figure 1). Patients were classified as late testers on the following grounds: 195 (74\%) of them had less than 200 CD4+ cells only, $12(4.5 \%)$ of them had an AIDS defining event prior or at entrance to care only, and $57(21.5 \%)$ of them had both. At the time of diagnosis, late testers in average tended to be older, were married in higher proportion, have higher rates of unemployment, a lower proportion of MSM, lower education and lower socioeconomic status when compared with non-late testers (table I).

\section{Prevalence and Risk factors associated with LT}

There was no change in the proportion of patients defined as LT over time during the period of observation

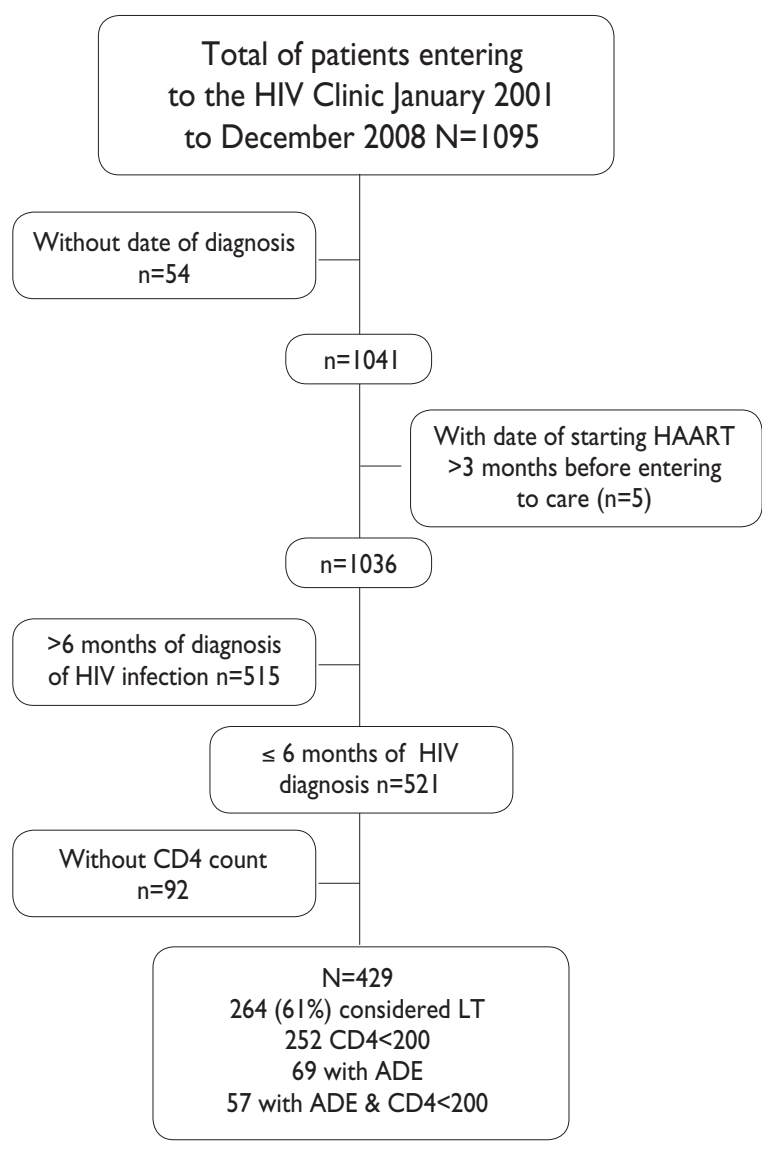

Figure I. Diagram of the eligibility of patients for ANALYSIS. ADE= AIDS DEFINING EVENT (STAGE C OF THE CDC criteria). Selection of patients done in Mexico City on March-ApRIL 2009

( $p=0.37$ ) (figure 2). We observed that patients older than 45 years $(p=0.03)$, unemployed $(p=0.04)$, married $(p=$ $0.04)$, and having less than nine years of education ( $p=$ 0.001) were at higher odds of late diagnosis that their counterparts. We also observed a gradient of decreased risk of late diagnosis as socioeconomic status improved ( $p=0.001$ and $p=0.04$ for middle and high socioeconomic level). In contrast, having being infected through homosexual sex was negatively associated to being a late tester $(p=0.04)$ (table II). However, when we fit a multivariable logistic regression model including all these variables only being older than 45 years old, being unemployed and having less than nine years of education were independently associated to late diagnosis of HIV infection (table II). 
Table I

Demographic ChaRACTERISTICS OF PATIENTS RECENTLY DIAGNOSED AS HIV-INFECTED DURING 200 I to 2008. AnAlysis done dURING ApriL-JUNe 2009 in Mexico City

\begin{tabular}{|c|c|c|c|}
\hline Risk factor & $\begin{array}{c}L T, N=264 \\
N(\%)\end{array}$ & $\begin{array}{c}N L T, N=165 \\
N(\%)\end{array}$ & p-value \\
\hline Female & $32(12)$ & I5(9) & 0.33 \\
\hline \multicolumn{4}{|l|}{ Age } \\
\hline$<34$ years & $132(50)$ & $103(62)$ & \\
\hline $34-45 y e a r s$ & $87(33)$ & $44(27)$ & 0.028 \\
\hline$>=45$ years & $45(17)$ & $18(11)$ & \\
\hline Married & $46(17)$ & $17(10)$ & 0.04 \\
\hline Unemployed & III(45) & $57(35)$ & 0.04 \\
\hline \multicolumn{4}{|l|}{ Transmission route } \\
\hline No MSM* & 103(39) & $48(29)$ & 0.04 \\
\hline Education ( $\leq 9$ years) & $90(34)$ & $29(17)$ & $<0.001$ \\
\hline \multicolumn{4}{|l|}{ Socioeconomic status } \\
\hline Low & $83(31)$ & $30(18)$ & \\
\hline Middle & $110(42)$ & $90(55)$ & 0.006 \\
\hline High & $71(27)$ & $45(27)$ & \\
\hline
\end{tabular}

\section{Discussion}

In this cross-sectional study of HIV-infected patients entering to health care in an HIV / AIDS Clinic in Mexico City, we observed that a high proportion $(61 \%)$ of the patients recently diagnosed with HIV infection, were tested in an advanced stage of the disease. Moreover, we found that the prevalence of late testers did not decrease between 2001 and 2008. Increasing age, low level of education and unemployment were independently associated to late test of HIV in our clinic. Previous reports form high-income countries have observed that the proportion of late testers may vary from 10 to $39 \%$ when using a similar definition to ours. ${ }^{10,20-23}$ The prevalence of late diagnosis in developing countries seems to be higher, but fewer studies have addressed this issue. Reports from Sub-Saharan Africa and Latin America have found a higher prevalence of late testers than in wealthy countries, but the use of different definitions makes comparisons difficult. 18,21,24-29 For instance, the prevalence of late testing in Venezuela was $40 \%$ as defined as stage $B$ or $C$ from the CDC (1993), ${ }^{18}$ but was $65 \%$ in Haiti defined as those diagnosed with CD4+ cell count lower than 350 cells $/ \mathrm{mL} .^{28}$

A very important finding of our study is the fact that in our center, the tendency of late diagnosis did not decrease during the study period. Different cohorts in France and the UK reported a similar tendency at the beginning of the last decade. ${ }^{20}$ More recently however, in a large cohort of 14 sites in the USA and Canada (NA-

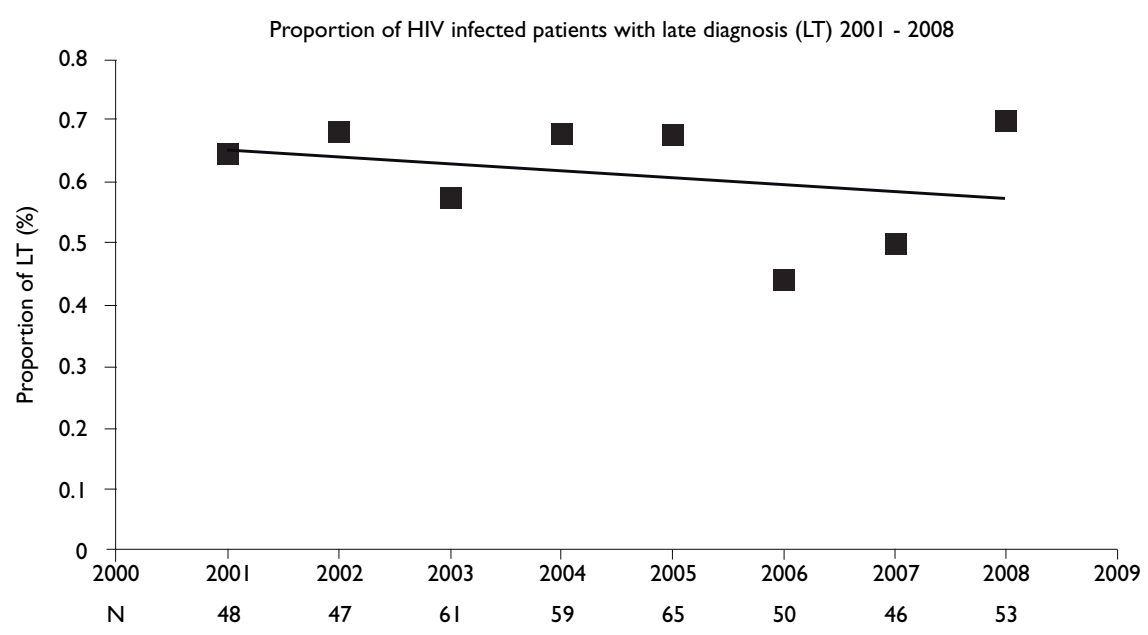

Figura 2. Proportion of HiV infected patients with late diagnosis along time (200I to 2008) p=0.37. Analysis done in Mexico City on May 2009 
Table II

Univariate and Multivariate analysis of factors associated to late testing.

Analysis done in Mexico City during April-June 2009

\begin{tabular}{|c|c|c|c|c|}
\hline \multirow[t]{2}{*}{ Risk factor } & \multicolumn{2}{|c|}{ Univariate analysis } & \multicolumn{2}{|c|}{ Multivariate analysis } \\
\hline & Odds ratio & $p$-value & Odds ratio & $p$-value \\
\hline \multicolumn{5}{|l|}{ Sex } \\
\hline Female & I & & $\mathrm{I}$ & \\
\hline Male & I.4 (0.7-2.6) & 0.33 & $0.5(0.2-1.2)$ & 0.12 \\
\hline \multicolumn{5}{|l|}{ Age } \\
\hline$<34$ years & 1 & - & I & - \\
\hline $34-45$ years & $1.5(0.9-2.4)$ & 0.06 & $1.6(0.9-2.6)$ & 0.06 \\
\hline$\geq 45$ years & $1.9(1.1-3.6)$ & 0.03 & $2.4(1.2-4.7)$ & 0.01 \\
\hline Married & $1.8(1.01-3.3)$ & 0.04 & I.32 (0.67-2.58) & 0.41 \\
\hline \multicolumn{5}{|c|}{ Transmission route } \\
\hline MSM & 1 & & $\mathrm{I}$ & \\
\hline no MSM & $1.56(1.02-2.37)$ & 0.04 & $1.14(0.67-1.95)$ & 0.61 \\
\hline Unemployed & $1.53(1.02-2.30)$ & 0.04 & $1.75(1.12-2.75)$ & 0.014 \\
\hline \multicolumn{5}{|c|}{ Socioeconomic Status } \\
\hline Low & 1 & - & I & - \\
\hline Middle & $0.44(0.27-0.73)$ & 0.001 & $0.65(0.36-1.15)$ & 0.137 \\
\hline High & $0.57(0.32-0.99)$ & 0.04 & $0.83(0.41-1.68)$ & 0.614 \\
\hline
\end{tabular}

\begin{tabular}{|c|c|c|c|c|}
\hline \multicolumn{5}{|l|}{ Education } \\
\hline$>9$ years & I & & I & \\
\hline$\leq 9$ years & $2.42(1.51-3.90)$ & $<0.001$ & $2.44(1.37-4.33)$ & 0.002 \\
\hline \multicolumn{5}{|l|}{ Period } \\
\hline $200 \mid-2002$ & I & - & I & - \\
\hline 2003-2004 & $0.84(0.48-1.48)$ & 0.56 & $0.83(0.45-I .5 \mathrm{I})$ & 0.546 \\
\hline $2005-2006$ & $0.68(0.39-1.20)$ & 0.19 & $0.76(0.42-1.39)$ & 0.380 \\
\hline $2007-2008$ & $0.78(0.43-1.40)$ & 0.41 & $0.6 \mathrm{I}(0.3 \mathrm{I}-\mathrm{I} .19)$ & 0.151 \\
\hline
\end{tabular}

ACCORD), late presentation to care seem to have been decreasing between 1997 and 2007, based on the change in the median of CD4+ count at presentation to care. ${ }^{29}$ The trend in the prevalence of late testing over time has not been described before in developing countries.

The relevance of our study can be better understood in the context of the evolution of universal access program to ARV drugs in Mexico and its lack impact on the AIDS associated mortality at on the population level. ${ }^{15}$ The program of universal free access to ARV drugs in Mexico rapidly expanded between 2000 and
2004, reaching 99\% coverage in 2004 and consolidated afterwards. ${ }^{30,31}$ Despite this impressive achievement, the mortality attributed to AIDS, has not significantly decreased in Mexico since 1996, when it reached its peak at 4.7 deaths per 100000 people. ${ }^{15}$ There are several explanations that may account for this unexpected lack of effect on mortality as opposed to what occurred in other Latin American countries and elsewhere after the scaling-up programs of ARV therapy: ${ }^{27,32}$ first, an increase in the incidence of HIV transmission in previous years; second, a high proportion of patients starting 
treatment at advanced stages of the disease and dying shortly after being diagnosed late (even before starting treatment); and third, sub-optimal treatment for HIV infected patients requiring ARV drugs.

In this article, we present evidence that late testing may be one factor that has contributed to the lack of reduction in AIDS associated mortality after the implementation of the universal access to ARV program in Mexico. ${ }^{15,30}$ The Mexican guidelines for ARV therapy -as opposed to others in low and middle-income countries before the 2010 (for instance Argentina, Chile, Peru, Colombia and Venezuela among others) recommended to start HAART when CD4+ T cell count decrease to 350 cells / $\mathrm{mL}$ or lower. ${ }^{33-38}$ The latter suggests that delayed therapy in our country can be attributed, at least partially to late diagnosis. Other factors contributing to delayed therapy initiation and lack of decrease in mortality are lack of linkage between diagnosis and care, which results in a late presentation to medical attention. ${ }^{39}$

Finally, we observed that patients older than 45 years, unemployed or with an educational level below the national median were at increased odds of late diagnosis than their counterparts. Older age and lower educational level have been previously identified as associated to late diagnosis ${ }^{11,13,40,41}$ but not unemployment. The interpretation of this finding is difficult, considering the limitations of the study in terms of design and data collection methods. Employment status could well indicate both a lack of access to health care services and explain the delayed in diagnosis or be the result of a severe, disabling disease. Other variables associated to late diagnosis in this study (being married, having a low socioeconomic status, heterosexuals and being a man not having reported to have had sex with other man) have also been observed previously to be associated to late diagnosis and as discussed by previous authors associated to perceptions of not being at risk of infection. ${ }^{13,42}$

The HIV / AIDS epidemic in Mexico is concentrated among MSM and male sex workers. Other groups considered at risk are Injecting Drug users (IDUs) and female sex workers. ${ }^{43}$ Accordingly, HIV prevention campaigns carried out by the Mexican Ministry of Health in recent years have targeted all these groups and the response plan to prevent and control HIV in Mexico for 2007-2012 focus its effort, in terms of VCT programs, in "high-risk" populations ${ }^{43}$ following the recommendations by the WHO/UNAIDS for regions with concentrated epidemics. ${ }^{44}$ In this study, we observed that people not traditionally considered at "high-risk" for HIV, as mentioned earlier were at increased risk of being diagnosed at advanced stages of the disease. Furthermore, we also observed that those men who reported not having had sex with men were also at increased risk of late diagnosis, even though in the multivariate analysis this variable lost statistical significance (OR: 1.14; 95\% CI 0.67-1.95). In our view, this finding is also worthy of further consideration due to its probable implications for HIV-testing policies. First, an unintended consequence of the success story of prevention campaigns in Mexico might have been the excess of morbidity and mortality imposed on those that are not considered at risk, by excluding them from awareness campaigns. Other contributing factors can be associated to social vulnerability and reflect the barriers to timely access to testing and care as low education, older age and unemployment were all independently associated to an increase odds of late diagnosis, as it has been observed in other reports from developed countries. ${ }^{11,13,31,45-49}$ Another explanation for this finding worth considering, is that it may have resulted as a bias arising from under self-reporting of homosexual sexual intercourse among men not identified themselves as "gay" or "homosexu$\mathrm{al}^{\prime \prime}$, but nonetheless, at risk. In recent years, vulnerable groups at increased risk of HIV-infection, such as prison inmates, migrants and others have been identified in Mexico, and even though the routes of transmission have not been clearly identified, sex with other men is thought to play at least some role. ${ }^{43,50-51}$ In any case, the expansion of voluntary counseling and testing services to wider sectors of the population would solve any of the problems over which we speculate here. Another factor worth considering as a contributor to delayed testing is the legal requirement of written and signed informed consent for all HIV-tests except for screening in blood banks and pregnant women. ${ }^{52}$

Our results support the need of reconsidering the current prevention strategies and expanding early access to voluntary counseling and testing to other subgroups of the population not traditionally considered at risk or even to the general population in order to prevent the potential harmful consequences of late HAART initiation. Also we need to implement better strategies to have recently diagnosed patients enter into care in a smooth and expeditious manner. The Mexican health system currently does not facilitate this transition because many centers still wait for confirmation of HIV infection with Western Blot before initiating antiretroviral therapy, ${ }^{52}$ which may take one or two additional months. The implementation of policies similar to the CDCs recommendation of offering HIV-testing to all people 13-64 years of age in clinical care settings may contribute to this purpose..$^{53}$ The implementation of universal testing would improve the clinical outcome of subjects receiving earlier ARV treatment, ${ }^{2-4}$ and in a large scale prevent transmission of HIV. ${ }^{54,55}$ 
These findings need to be corroborated by information from other centers, multisite studies or both, as one of the limitations of our study is that it was conducted in a single, tertiary care, referral center in a large urban area. The population cared for in our institution, is unlikely to be representative of the Mexican population seeking health care services and different mechanism of selection bias may have operated in both directions. Other limitations of the study arise from its retrospective design. We have tried to limit the bias and measurement error that collecting retrospective information carries by including only incident cases and clearly defining our outcome of interest. However, as the collection of the data for independent variables is based on clinical charts, our capacity to explore barriers for an early diagnosis in our population is limited. For example, in a recent study in an HIV / AIDS clinic in Tijuana HIV infected patients with late diagnosis were interviewed to identify the associated risk factors associated and variables not collected in clinical charts such as the preference of not knowing to be infected due to stigma; exposure to peers engaging in high-risk sexual behavior had a stronger correlation with late diagnosis than demographic information commonly collected for clinical purposes. ${ }^{56}$ Recent findings of our group in this population seem to corroborate that stigma and psychological characteristics have an important role in the decision to delay HIV testing. ${ }^{57}$

In conclusion, in our center, late diagnosis is the most common presentation to clinical care and the frequency of this phenomenon has not changed in the past eight years. The independent risk factors associated with late-diagnosis were older age, low level of education and being unemployed at entrance, as reported in other cohorts and not belonging to "high-risk" groups. Even though more research is needed to corroborate our data, our initial findings points out to the need to make HIV-testing widely available and less restrictive in Mexico. We propose that the current focalized and limiting HIV-testing policies in Mexico need to be revised.

Declaration of conflict of interests: BCR has been a speaker for BMS and MSD, and received a grant for clinical trial from MSD; YCV and FBZ declared no conflict; JSM has been a speaker for ViiV and Stendahl and has received a grant for research from Pfizer, and declared no conflict.

\section{References}

I. Pallela FJ, Delaney KM, Moorman AC, Loveless MO, Fuhrer J, Satten GA, et al. Declining morbidity and mortality among patients with advanced Human Immunodeficiency Virus infection. New Engl J Med 1998;338(I3):853-860.
2. When To Start Consortium, Sterne JA, May M, Costagliola D, de Wolf F, Phillips AN, et al. Timing of initiation of antiretroviral therapy in AIDSfree HIV-I-infected patients: a collaborative analysis of 18 HIV cohort studies. Lancet 2009;373(9672): 1352-1363. Epub 2009 Apr 8.

3. NA-ACCORD Investigators, Kitahata MM, Gange SJ, Abraham AG, Merriman B, Saag MS, et al. Effect of early versus deferred antiretroviral therapy for HIV on survival. N Engl J Med 2009;360(18):1815-1826. Epub 2009 Apr I.

4. Mocroft A, Ledergerber B, Katlama C, Kirk O, Reiss P, d'Arminio MA, et al. Decline in the AIDS and death rates in the EuroSIDA study: an observational study. Lancet 2003;362 (9377):22-29.

5. Severe P, Juste MA, Ambroise A, Eliacin L, Marchand C, Apollon S, et al. Early versus standard antiretroviral therapy for HIV-infected adults in Haiti. N Engl J Med 2010; 363(3):257-265. PubMed PMID: 2064720 I. 6. Mills E, Bakanda C, Birungi J, Mwesigwa R, Chan K, Ford N, et al. Mortality by baseline CD4 cell count among HIV patients initiating antiretroviral therapy: evidence from a large cohort in Uganda. AIDS 20I I; 25(6):85I-855.

7. Castilla J, Del Romero J, Hernando V, Marincovich B, García S, Rodríguez $\mathrm{C}$. Effectiveness of highly active antiretroviral therapy in reducing heterosexual transmission of HIV. J Acquir Immune Defic Syndr 2005;40(I):96-101.

8. Lima VD, Johnston K, Hogg RS, Levy AR, Harrigan PR, Anema A, et al. Expanded access to highly active antiretroviral therapy: a potentially powerful strategy to curb the growth of the HIV epidemic. J Infect Dis 2008; 198(I):59-67.

9. Barry SM, Lloyd-Owen SJ, Madge SJ, Cozzi-Lepri A, Evans AJ, Phillips AN, et al. The changing demographics of new HIV diagnoses at a London centre from 1994 to 2000. HIV Med 2002;3(2):129-134.

10. Sabin C, Smith C], Gumley H, Murphy G, Lampe FC, Phillips AN, et al. Late presenters in the era of highly active antiretroviral therapy: uptake of and responses to antiretroviral therapy. AIDS 2004;|8(I6):2|45-215I. II. Girardi E, Aloisi MS, Arici C, Pezzotti P, Serraino D, Balzano R, et al. for the ICoNA Behavioral Epidemiology Study Group. Delayed presentation and late testing for HIV: demographic and behavioral risk factors in a multicenter study in Italy. J Acquir Immune Defic Syndr 2004;36(4):95 I959. PubMed PMID: I5220702.

12. The UK Collaborative HIV Cohort (UK CHIC) Steering Committee UK, Sabin CA, Schwenk A, Johnson MA, Gazzard B, Fisher M, Walsh J, et al. Late diagnosis in the HAART era: proposed common definitions and associations with mortality. AIDS 2010;24(5):723-727. PubMed PMID: 20057312.

13.Fisher M. Late diagnosis of HIV infection: major consequences and missed opportunities. Curr Opin Infect Dis 2008; 21:1-3.

14. World Health Organization. Approaches to rationing antiretroviral treatment: ethical and equity implications. Bull World Health Org 2005;83(7):54I-547.

15. Magis-Rodríguez C, Bravo E, Gayet C, Rivera P, De Luca M. El VIH y el SIDA en México al 2008, hallazgos, tendencias y reflexiones. México, D.F.: CENSIDA, 2008: P. 88 [Accessed 22 March 20II]. Available from: http://www.censida.salud.gob.mx/descargas/biblioteca/VIHSIDA_ MEX2008.pdf

16. Nash D, Katyal M, Brinkhof MW, Keiser O, May M, Hughes R, et al. ART-LINC Collaboration of leDEA. Long-term immunologic response to antiretroviral therapy in low-income countries: a collaborative analysis of prospective studies. AIDS 2008;22(I7):229I-2302.

17. Tuboi SH, Schechter M, McGowan CC, Cesar C, Krolewiecki A, Cahn $\mathrm{P}$, et al. Mortality during the first year of potent antiretroviral therapy in HIV-I-infected patients in 7 sites throughout Latin America and the Caribbean. J Acquir Immune Defic Syndr 2009; 5 I (5):615-623.

18. Bonjour M, Montagne M, Zambrano M, Molina G, Lippuner C, Wadskier FG, et al. Determinants of late disease-stage presentation at diagnosis of HIV infection in Venezuela: A case-case comparison. AIDS Res Ther 2008;5:6. 
19. Centers for Disease Control and Prevention. Revised surveillance case definitions for HIV infection among adults, adolescents, and children aged $<18$ months and for HIV infection and AIDS among children aged 18 months to <13 years. 2008; MMWR57 (No.RR-10): I-16 [Accessed 22 March 20I I]. Available from: http://www.cdc.gov/mmwr/PDF/rr/rr57/0.pdf 20. Adler A, Mounier-Jack S, Coker RJ. Late diagnosis of HIV in Europe: definitional and public health challenges. AIDS Care 2009;2I(3):284-293. 21. Keruly J, Moore R. Immune status at presentation to care did not improve among antiretroviral-naive persons from 1990 to 2006. Clin Infect Dis 2007;45:1369-1374.

22. Borghi V, Girardi E, Bellelli S, Angeletti C, Mussini C, Porter K, et al. Late presenters in an HIV surveillance system in Italy during the period 1992-2006. J Acquir Immune Defic Syndr 2008;49:282-286.

23. Guy RJ, McDonald AM, Bartlett MJ, Murray JC, Giele CM, Davey TM, et al. Characteristics of HIV diagnoses in Australia, 1993-2006. Sexual Health 2008;5(2):91-96.

24. Kigozi IM, Dobkin LM, Martin JN, Geng EH, Muyindike W, Emenyonu $\mathrm{NI}$, et al. Late-disease stage at presentation to an HIV Clinic in the era of free antiretroviral therapy in Sub-Saharan Africa. J Acquir Immune Defic Syndr 2009;52(2):280-289.

25. Kassa E, Rinke de Wit TF, Hailu E, Girma M, Messele T, Mariam HG et al. Evaluation of the World Health Organization staging system for HIV infection and disease in Ethiopia: association between clinical stages and laboratory markers. AIDS 1999;13(3):38I-389.

26. Malamba SS, Morgan D, Clayton T, Mayanja B, Okongo M, Whitworth J. The prognostic value of the World Health Organization staging system for HIV infection and disease in rural Uganda. AIDS 1999;।3(I8):2555-2562.

27. The Antiretroviral Therapy in Lower Income Countries (ARTLINC) Collaboration and ART Cohort Collaboration (ART-CC) groups, Braitstein P, Brinkhof MW, Dabis F, Schechter M, Boulle A, Miotti P, et al. Mortality of HIV-I-infected patients in the first year of antiretroviral therapy: comparison between low-income and high-income countries. Lancet 2006;367(95|3):817-824.

28. Louis C, Ivers LC, Smith F, Freedberg KA, Castro A. Late presentation for HIV care in central Haiti: factors limiting access to care. AIDS Care 2007;4:487-491.

29. Althoff KN, Gange SJ, Klein MB, Brooks JT, Hogg RS, Bosch RJ, et al. Late presentation for Human Immunodeficiency Virus care in the United States and Canada. Clin Infect Dis 2010; 50(II):15I2-I520.

30. Bautista A S, Mane A, Bertozzi SM. Economic impact of antiretroviral therapy prescription decisions in the context of rapid scaling-up of access to treatment. AIDS 2006;20(I):10I-109.

31. Magis C, Hernández M. Epidemiología del SIDA en México. En: Cordova VJ, Ponce de L S, Valdespino JL. 25 años de SIDA en México: logros, desaciertos y retos. 2a. edición. México: CENSIDA, 2009:10I-II7. [Accessed 22 March 20I I]. Disponible en: http://www.censida.salud.gob. $\mathrm{mx} /$ descargas/SIDA25axos-26mar.pdf

32. Marazzi MC, Liotta G, Germano P, Guidotti G, Altan AD, Ceffa S, et al. Excessive early mortality in the first year of treatment in HIV type I-infected patients initiating antiretroviral therapy in resource-limited settings. AIDS Res Hum Retroviruses 2008;24(4):555-560.

33. Ministerio de Salud. Recomendaciones para el tratamiento antirretroviral 2007. Argentina; 2007. [Accessed 22 March $201 \mathrm{I}$ ]. Available from: http://www.msal.gov.ar/sida/pdf/info-equipos-salud /recomendacionestratamiento-antirretroviral.pdf.

34. Ministerio de Salud. Guía clínica síndrome de la inmunodeficiencia adquirida VIH/SIDA. Santiago: Ministerio de Salud, 2005.

35. Ministerio de Salud. Guía nacional de atención integral de la persona viviendo con el VIH /SIDA. (PVVIH/S). 2a. edición. Lima, 2006. [Accessed 22 March $20 \mathrm{II}$ ]. Available from: http://www.care.org.pe/Websites/FondoMundial/materiales/TB-VIH/VIH/VIH4/Gu\%C3\%ADa\%20Nacional\%20 Atenci\%C3\%B3n\%20Integral.pdf.
36. Ministerio de protección y fundación para la investigación y el desarrollo de la salud y la seguridad social. Guía para el manejo de VIH/SIDA basada en la evidencia. Bogotá, 2005 [Accessed 22 March 20I I]. Available from: http://www.saludcolombia.com/actual/documentos/GUIA\%20 DE\%20ATENCION\%20VIH-SIDA\%20version\%20oficial.pdf 37. Ministerio del poder popular para la salud. Guía para el manejo del tratamiento antirretroviral de las personas que viven con el VIH/SIDA en Venezuela Programa Nacional de SIDA/ITS 2008-2009. 3a. edición. Caracas, 2008. [Accessed 22 March 20I I]. Available from: http://www. mpps.gob.ve/Boletines/sida/Guia_TARV.pdf

38. Centro nacional para la prevención y el control de VIH/SIDA. Guía de manejo antirretroviral de las personas con $\mathrm{VIH}$. 4a. edición. México: CENSIDA, 2009. [Accessed 22 March 201 I]. Available from: http://www. censida.salud.gob.mx/descargas/biblioteca/guia_arv09.pdf.

39. Crabtree-Ramírez B, Caro-Vega Y, Shepherd BE, Wehbe F, Cesar C, Cortes $C$ et al. 20I I Cross-sectional analysis of late HAART initiation in Latin America and the Caribbean: late testers and late presenters. PLoS ONE 6(5): e20272. doi:10.137//journal.pone.0020272

40. Centers for Disease Control and Prevention. Late versus early testing of HIV sites, United States, 2000-2003. MMWR Morb Mortal Wkly Rep 2003;32:58I-586.

4I. Castilla J, Sobrino P, de la Fuente L, Noguer I, Guerra L and Parras F. Late diagnosis of HIV infection in the era of highly active antiretroviral therapy: consequences for AIDS incidence. AIDS 2006; 16:1945-1951. 42. Girardi E, Sabin C, Monforte AD. Late Diagnosis of HIV Infection: Epidemiological features, consequences and strategies to encourage earlier testing. J Acquir Immune Defic Syndr 2007;46(Supp I):S3-S8.

43. Programa de acción específico, 2007-20I2 en respuesta al VIH/SIDA e ITS; Secretaría de Salud, Subsecretaría de Prevención y Promoción de la Salud. México, 2008:27-35. [Accessed 22 March 20I I]. Available from: http:// www.censida.salud.gob.mx/descargas/biblioteca/ProgAc2007-20I2.pdf 44. World Health Organization. Guidance on provider-initiated HIV testing and counseling in health facilities. May 2007. [Accessed 22 March $20 \mathrm{II}$. Available from: http://www.who.int/mediacentre/news/ releases/2007/pr24/en/index.html

45. McDonald AM, Li Y, Dore GJ, Ree H, Kaldor JM. Late HIV presentation among AIDS cases in Australia, 1992-200I. Aust NZJ Public Health 2003;(6):608-613.

46. Krentz HB, Auld MC, Gill MJ. The high cost of medical care for patients who present late (CD4, 200cells/microL) with HIV infection. HIV Med 2004;5:93-98.

47. Sullivan AK, Curtis H, Sabin CA, Johnson MA. Newly diagnosed HIV infections: review in UK and Ireland. BMJ 2005;330(7503): I30I-I302. 48. Delpierre C, Dray-Spira R, Cuzin L, Marchou B, Massip P, Lang T, et al. VESPA Study Group. Correlates of late HIV diagnosis: implications for testing policy. Int J STD AIDS 2007; 18(5):3 I2-3I7.

49. Brännström J, Akerlund B, Arneborn M, Blaxhult A, Giesecke J. Patients unaware of their HIV infection until AIDS diagnosis in Sweden 1996-2002. Int J STD AIDS 2005; 16(I0):702-706.

50. Donate AP, Rangel MG, Hovell MF, Santibáñez J, Sipan CL, Izazola JA. HIV infection in mobile populations: the case of Mexican migrants to the United States. Rev Panam Salud Publica 2005; 17(I):26-29. PubMed PMID: I5720878.

5I. Essuon AD, Simmons DS, Stephens TT, Richter D, Lindley LL, Braithwaite RL. Transient populations: linking HIV, migrant workers, and South African male inmates. J Health Care Poor Underserved 2009;20(Suppl 2):40-52. Review

52. Secretaria de Salud. Norma Oficial Mexicana NOM-010-SSA2-1993, para la prevención y control de la infección por virus de la inmunodeficiencia humana. México, 1993. [Accessed 22 March $201 \mathrm{I}$ ]. Available from: http://www.salud.gob.mx/unidades/cdi/nom/0I0ssa23.html 
53. Branson BM, Handsfield HH, Lampe MA, Janssen RS, Taylor AW, Lyss $S B$, et al. Centers for Disease Control and Prevention (CDC). Revised recommendations for HIV testing of adults, adolescents, and pregnant women in health-care settings. MMWR Recomm Rep 2006; 55(RR-I4):I-I7; quiz CEI-4.

54. Donnell D, Kiarie J, Thomas K, Baeten J, Lingappa J, Cohen C, et al. ART and risk of heterosexual HIV-I transmission in HIV-I serodiscordant african couples: a multinational prospective study. 17th Conference on retroviruses and opportunistic infections (CROI 20I0). San Francisco, USA. February 16-19, 2010. Abstract 136.

55. Bethesda, MD: National Institute of Allergy and Infectious Diseases. Treating HIV-infected people with antiretrovirals protects partners from infection: Findings result from $\mathrm{NIH}$-funded international study [press release]; [Accessed: May 12, 20I I]. Available from: http://www.niaid.nih. gov/news/newsreleases/201 I/Pages/HPTN052.aspx

56. Carrizosa CM, Blumberg EJ, Hovell MF, Martinez-Donate AP, GarciaGonzalez G, Lozada R, et al. Determinants and prevalence of late HIV testing in Tijuana, Mexico. AIDS Patient Care and STDs 20 I0;24(5):333-340. 57. Nogueda-Orozco MJ, Caro-Vega Y, Crabtree-Ramírez B, VázquezPineda F, Sierra-Madero J. Inicio tardío de tratamiento antirretroviral: ¿Qué factores psicosociales están involucrados? XXXVI Congreso Nacional de Infectología y Microbiología Clínica. Puebla, Junio 201 I. Abstract $\mathrm{H} 7$. 